\title{
QUEEN'S
UNIVERSITY
BELFAST
}

\section{Actions of PGLa-AM1 and its [A14K] and [A20K] analogues and their therapeutic potential as anti-diabetic agents}

Owolabi, B. O., Musale, V., Ojo, O. O., Moffett, R. C., McGahon, M. K., Curtis, T. M., Conlon, J. M., Flatt, P. R., \& Abdel-Wahab, Y. H. A. (2017). Actions of PGLa-AM1 and its [A14K] and [A20K] analogues and their therapeutic potential as anti-diabetic agents. Biochimie, 138, 1-12. https://doi.org/10.1016/j.biochi.2017.04.004

\section{Published in:}

Biochimie

\section{Document Version:}

Peer reviewed version

Queen's University Belfast - Research Portal:

Link to publication record in Queen's University Belfast Research Portal

\section{Publisher rights}

(C) 2017 Elsevier B.V. This manuscript is distributed under a Creative Commons Attribution-NonCommercial-NoDerivs License

(https://creativecommons.org/licenses/by-nc-nd/4.0/), which permits distribution and reproduction for non-commercial purposes, provided the author and source are cited.

\section{General rights}

Copyright for the publications made accessible via the Queen's University Belfast Research Portal is retained by the author(s) and / or other copyright owners and it is a condition of accessing these publications that users recognise and abide by the legal requirements associated with these rights.

\section{Take down policy}

The Research Portal is Queen's institutional repository that provides access to Queen's research output. Every effort has been made to ensure that content in the Research Portal does not infringe any person's rights, or applicable UK laws. If you discover content in the Research Portal that you believe breaches copyright or violates any law, please contact openaccess@qub.ac.uk. 
Actions of PGLa-AM1 and its [A14K] and [A20K] analogues and their therapeutic potential as anti-diabetic agents

Bosede O. Owolabi ${ }^{\text {a }}$, Vishal Musale ${ }^{\mathrm{a}}$, Opeolu O. Ojo ${ }^{\mathrm{a}}$, R. Charlotte Moffett ${ }^{\mathrm{a}}$, Mary K.

McGahon $^{\mathrm{b}}$, Tim M. Curtis ${ }^{\mathrm{b}}$, J. Michael Conlon ${ }^{\mathrm{a}^{*}}$, Peter R. Flatt ${ }^{\mathrm{a}}$ and Yasser H. A. Abdel-Wahab ${ }^{\mathrm{a}}$

${ }^{\mathrm{a} S A A D}$ Centre for Pharmacy \& Diabetes, School of Biomedical Sciences, University of Ulster, Coleraine, BT52 1SA, UK

${ }^{\mathrm{b}}$ Centre for Experimental Medicine, Queen's University of Belfast, Belfast, BT9 7BL, UK.

*Corresponding author: J. Michael Conlon, School of Biomedical Sciences, University of Ulster, Coleraine, BT52 1SA, Northern Ireland, UK. E-mail: m.conlon@ulster.ac.uk 


\section{ABSTRACT}

PGLa-AM1 (GMASKAGSVL ${ }^{10}$ GKVAKVALKA ${ }^{20}$ AL. $\mathrm{NH}_{2}$ ) was first identified in skin secretions of the frog Xenopus amieti (Pipidae) on the basis of its antimicrobial properties. PGLa-AM1 and its [A14K] and [A20K] analogues produced a concentration-dependent stimulation of insulin release from BRIN-BD11 rat clonal $\beta$-cells without cytotoxicity at concentrations up to $3 \mu \mathrm{M}$. In contrast, the $[\mathrm{A} 3 \mathrm{~K}]$ was cytotoxic at concentrations $\geq 30 \mathrm{nM}$. The potency and maximum rate of insulin release produced by the $[\mathrm{A} 14 \mathrm{~K}]$ and $[\mathrm{A} 20 \mathrm{~K}]$ peptides were significantly greater than produced by PGLa-AM1. [A14K]PGLa-AM1 also stimulated insulin release from mouse islets at concentrations $\geq 1 \mathrm{nM}$ and from the 1.1B4 human-derived pancreatic $\beta$-cell line at concentrations $>30 \mathrm{pM}$. PGLa-AM1 $(1 \mu \mathrm{M})$ produced membrane depolarization in BRIN-BD11 cells with a small, but significant $(\mathrm{P}<0.05)$, increase in intracellular $\mathrm{Ca}^{2+}$ concentrations but the peptide had no direct effect on $\mathrm{K}_{\mathrm{ATP}}$ channels. The [A14K] analogue $(1 \mu \mathrm{M})$ produced a significant increase in cAMP concentration in BRIN-BD11 cells and down-regulation of the protein kinase A pathway by overnight incubation with forskolin completely abolished the insulin-releasing effects of the peptide. [A14K]PGLa-AM1 (1 $\mu \mathrm{M})$ protected against cytokine-induced apoptosis $(p<0.001)$ in BRIN-BD11 cells and augmented $(p<0.001)$ proliferation of the cells to a similar extent as GLP-1. Intraperitoneal administration of the $[\mathrm{A} 14 \mathrm{~K}]$ and $[\mathrm{A} 20 \mathrm{~K}]$ analogues $(75 \mathrm{nmol} / \mathrm{kg}$ body weight) to both lean mice and high fat-fed mice with insulin resistance improved glucose tolerance with a concomitant increase in insulin secretion. The data provide further support for the assertion that host defense peptides from frogs belonging to the Pipidae family show potential for development into agents for the treatment of patients with Type 2 diabetes. 
Keywords: PGLa-AM1, Type 2 diabetes, Amphibian skin peptide, Insulin-release, $\beta$-cell proliferation; Anti-apoptotic peptide

\section{Abbreviations:}

CCK-8, Cholecytokinin-8

$\mathrm{CPF}$, Caerulein precursor fragment

EGTA, ethylene glycol tetraacetic acid

GLP-1, Glucagon-like peptide 1

HEPES, 4-(2-hydroxyethyl)-1-piperazineethanesulfonic acid

IBMX, 3-isobutyl-1-methylxanthine

KRB, Krebs-Ringer bicarbonate buffer

LDH, Lactate dehydrogenase

MALDI-TOF, Matrix-assisted laser desorption/ionization-time of flight

PGLa. Peptide glycine-leucine-amide

PKA, Protein kinase A

PKC, Protein kinase C

PMA, phorbol 12-myristate 13-acetate

T2DM, Type 2 diabetes mellitus 


\section{Introduction}

The order Anura (frogs and toads) currently contains 6660 well characterized species [1] and their skin secretions represent a vast reservoir of compounds with therapeutic potential for drug development. More than 1000 frog skin peptides have been described that possess antimicrobial activity with varying degrees of cytotoxicity against eukaryotic cells and it is postulated that they defend the host against invasion by pathogenic microorganisms in the environment $[2,3]$. It is now appreciated that these peptides are multi-functional and they may also display immunomodulatory, antioxidant, and chemoattractive properties [3,4]. In particular, several such peptides that were first identified on the basis of their antimicrobial activities have subsequently been found to display insulinotropic effects both in vitro using BRIN-BD1 1 clonal $\beta$ cells and in vivo in both lean and insulin-resistant obese mice (reviewed in [4,5]). Consequently, these hostdefense peptides show potential for development into drugs for the treatment of patients with Type 2 diabetes mellitus (T2DM).

Peptide glycine-leucine-amide (PGLa) was first identified in skin secretions of the South African frog Xenopus laevis [6] and subsequently othologs have been isolated from a wide range of species belonging to the genus Xenopus (reviewed in [7]). PGLa is best known for its broadspectrum antibacterial and antifungal activities and for its ability to act synergistically with magainin peptides [8,9]. Skin secretions of the octoploid frog Xenopus amieti contain two paralogous peptides related to PGLa: PGLa-AM1 (GMASKAGSVLGKVAKVALKAAL. $\mathrm{NH}_{2}$ ) and PGLa-AM2 (GMASTAGSVLGKLAKAVAIGAL.NH ${ }_{2}$ ) [10]. The more cationic PGLaAM1 shows greater growth-inhibitory potency against Escherichia coli and Staphylococcus aureus [10] and the peptide is also active against several oral pathogens at concentrations that do not affect the viability of oral fibroblasts [11]. The possibility that PGLa-AM1 may show 
potential for development into a drug for the treatment of T2DM is suggested by the observation that PGLa-AM1 stimulates the release of the potent incretin peptide glucagon-like peptide-1 from the GLUTag murine enteroendocrine cell line at concentrations that are not toxic to the cells [12]. The aim of the present study was to investigate the insulinotropic actions of PGLaAM1 in vitro using BRIN-BD1 1 rat clonal $\beta$-cells [13], 1.1B4 human-derived pancreatic $\beta$-cells [14], and dispersed isolated mouse islets and in vivo using both lean mice and mice fed a high fat diet to produce obesity and insulin resistance.

One of the major disadvantages of naturally occurring peptides as therapeutic agents is their relatively low potency and bioavailability but these limitations may be circumvented to varying degrees by the design of appropriate analogues [15]. Although lacking secondary structure in aqueous solution, PGLa adopts an amphipathic $\alpha$-helical conformation in a membrane-mimetic solvent (50\% trifluoroethanol-water) or in the presence of negatively charged phosphatidylcholine /phosphatidylglycerol (3:1) vesicles [16]. Secondary structure prediction using the AGADIR algorithm [17] indicates that PGLa-AM1 has the propensity to adopt a stable $\alpha$-helix from $\mathrm{Val}^{9}$ to Leu ${ }^{22}$. Previous studies with analogues of other $\alpha$-helical, frog skin host-defense peptides have shown that increasing cationicity by substitution of appropriate neutral or acidic amino acid residues by L-Lysine may produce more potent and effective insulin-releasing peptides [5,18-20]. Consequently, effects of increasing cationicity, by the substitutions by L-lysine of $\mathrm{Ala}^{14}$ and $\mathrm{Ala}^{20}$ within the $\alpha$-helical domain and Lys ${ }^{3}$ outside the domain, on the insulin-releasing and glucose-lowering activities of the peptide were investigated. In addition, the mechanism of action and effects of the peptides on proliferation and apoptosis in BRIN-BD11 cells were determined. 


\section{Materials and Methods}

2.1 Peptide synthesis and purification

PGLa-AM1 and its [A3K], [A14K] and [A20K] analogues were supplied in crude form by GL Biochem Ltd (Shanghai, China) and were purified to near homogeneity ( $>98 \%$ purity) by reversed-phase HPLC by reversed-phase HPLC on a (2.2-cm x 25-cm) Vydac 218TP1022 (C18) column (Grace, Deerfield, IL, USA) under the conditions previously described $[11,12]$. The identities of all peptides were confirmed by MALDI-TOF mass spectrometry using a Voyager DE PRO instrument (Applied Biosystems, Foster City, USA).

\section{2. $\quad$ In vitro insulin release studies using BRIN-BD11 and $1.1 B 4$ cells}

The procedure for studying the effects of peptides on the release of insulin from BRINBD11 rat clonal $\beta$-cells (passages 15-20) and 1.1B4 human-derived pancreatic $\beta$-cells (passages 25-28) has been described in detail previously $[13,14]$. Incubations with purified synthetic peptides $\left(10^{-12}-3 \times 10^{-6} \mu \mathrm{M} ; \mathrm{n}=8\right)$ were carried out for 20 min at $37{ }^{\circ} \mathrm{C}$ using Krebs-Ringer bicarbonate (KRB) buffer supplemented with $5.6 \mathrm{mM}$ glucose. After incubation, aliquots of cell supernatant were removed for insulin radioimmunoassay [21]. Incubations $(n=8)$ of BRINBD11 cells were also carried out in the presence of $30 \mathrm{mM} \mathrm{KCl}$ and $30 \mathrm{mM} \mathrm{KCl}+1 \mu \mathrm{M}$ [A14K]PGLa-AM1. 


\subsection{Insulin-release studies using isolated mouse islets}

Pancreatic islets were isolated from adult, male National Institutes of Health (NIH) Swiss mice (Harlan Ltd, Bicester, UK) as described [22]. After $48 \mathrm{~h}$ of culture under the same conditions as used for clonal cell lines, islets were pre-incubated with $500 \mu \mathrm{L} \mathrm{KRB}$ containing $0.1 \%$ bovine serum albumin, and $1.4 \mathrm{mM}$ glucose $(\mathrm{pH} 7.4)$ for $1 \mathrm{~h}$ at $37^{\circ} \mathrm{C}$. Incubations $(\mathrm{n}=8)$ with [A14K]PGLa-AM1(0.1 nM - 1 $\mu \mathrm{M})$, [A20K]PGLa-AM1 $(0.1 \mathrm{nM}-1 \mu \mathrm{M})$ and $1 \mu \mathrm{M}$ GLP-1 (positive control) were carried out for $1 \mathrm{~h}$ at $37{ }^{\circ} \mathrm{C}$ using KRB buffer supplemented with 16.7 $\mathrm{mM}$ glucose. Aliquots of supernatant were removed for insulin radioimmunoassay and the insulin content of the islets following acid-ethanol extraction was determined as previously described [23].

\subsection{Cytotoxicity assay}

The effects of peptides upon the integrity of the plasma membrane of BRIN-BD11 cells was determined by measurement of the rate of release of the cytosolic enzyme lactate dehydrogenase (LDH) using a CytoTox 96 non-radioactive cytotoxicity assay kit (Promega, Southampton, UK) according to the manufacturer's instructions as previously described $[18,19]$.

\subsection{Effects of peptides on membrane depolarization and intracellular calcium $\left(\left[\mathrm{Ca}^{2+}\right]_{i}\right)$}

The procedure for determining the effects of PGLa-AM1, [A14K]PGLa-AM1, and [A20K]PGLa-AM1 on membrane depolarization and intracellular $\mathrm{Ca}^{2+}$ concentrations 
monolayers of BRIN-BD11 cells has been described previously [18]. The cells were incubated at $37{ }^{\circ} \mathrm{C}$ for $300 \mathrm{~s}$ with $1 \mu \mathrm{M}$ test peptides, $5.6 \mathrm{mM}$ glucose only, $5.6 \mathrm{mM}$ glucose $+30 \mathrm{mM} \mathrm{KCl}$ and $5.6 \mathrm{mM}$ glucose $+10 \mathrm{mM}$ alanine.

\subsection{Patch clamp analysis}

Full details of the equipment and protocol for patch clamp analysis have been provided previously [23]. $\mathrm{K}_{\mathrm{ATP}}$ currents were measured during the application of a voltage ramp protocol which initially depolarized the membrane potential to $+20 \mathrm{mV}$ and then progressively hyperpolarized to $-80 \mathrm{mV}$ over the course of $1 \mathrm{~s}$. Ramps were applied every $5 \mathrm{~s}$ from a holding potential of $0 \mathrm{mV}$ and $\mathrm{K}_{\mathrm{ATP}}$ currents were selectively elicited by the application of high $\mathrm{K}+$ external solution containing (in $\mathrm{mM}$ ) $130 \mathrm{KCl}, 2.5$ glucose, 10 tetraethylammonium $\mathrm{Cl}, 1.3$ $\mathrm{MgCl}_{2}, 10 \mathrm{HEPES}, 2 \mathrm{CaCl}_{2}$, $\mathrm{pH} 7.4$ together with $100 \mathrm{nM}$ penitrem $\mathrm{A}$ and $1 \mu \mathrm{M}$ nimodipine to inhibit BK and L-Type $\mathrm{Ca}^{2+}$ channels respectively. The internal (pipette) solution was $\mathrm{K}^{+}$based (in mM) $130 \mathrm{KCl}, 0.045 \mathrm{CaCl}_{2}, 1 \mathrm{MgCl}_{2}, 1$ EGTA, 10 HEPES, $\mathrm{pH}$ 7.2). Prior to, and during application of $1 \mu \mathrm{M}$ PGLa-AM1, $\mathrm{K}_{\mathrm{ATP}}$ channel opening was stimulated by the addition of 200 $\mu \mathrm{M}$ diazoxide. Current amplitudes were sampled at $10 \mathrm{mV}$ intervals, normalized to membrane capacitance (a measure of cell surface area) and statistical analysis completed.

\subsection{Effects of PGLa-AM1 on cyclic AMP production}

The procedure for determining the effects of $1 \mu \mathrm{M}$ [A14K]PGLa-AM1 and $10 \mathrm{nM}$ GLP-1 (positive control) on the production of cAMP in BRIN-BD11 cells has been described 
previously [5]. Incubations were carried out for 20 min in KRB buffer supplemented with $5.6 \mathrm{mM}$ glucose and $200 \mu \mathrm{M}$ of the phophodiesterase inhibitor, 3-isobutyl-1-methylxanthine (IBMX). cAMP concentrations in the cell lysate were measured using a R \& D Systems Parameter kit (Abingdon, UK) following the manufacturer's recommended protocol.

\subsection{Effects of down-regulation of the PKA and PKC pathways on insulin release}

It has been shown that overnight culture of BRIN-BD11 cells with the activators of the protein kinase A (PKA) pathway, forskolin $(25 \mu \mathrm{M}$; Sigma-Aldrich, UK) or the protein kinase C (PKC) pathway, phorbol 12-myristate 13-acetate (PMA; $10 \mathrm{nM}$; Sigma-Aldrich, UK) blocks the stimulatory actions of compounds that activate the pathways [24]. Using a previously described procedure for down-regulation of these pathways [5], BRIN-BD11 cells were incubated for 20 min in KRB buffer supplemented with $5.6 \mathrm{mM}$ glucose containing (A) [A14K]PGLa-AM1 $(1 \mu \mathrm{M}),(\mathrm{B}) \mathrm{GLP}-1(10 \mathrm{nM})$ and $(\mathrm{C})$ CCK8 $(10 \mathrm{nM})$. Control incubations with forskolin $(25 \mu \mathrm{M})$, PMA $(10 \mathrm{nM})$ and forskolin $(25 \mu \mathrm{M})+$ PMA $(10 \mathrm{nM})$ were also carried out.

\subsection{Effects of [A14K]PGLa-AM1on cytokine-induced apoptosis in BRIN-BD11 cells}

For determination of the ability of [A14K]PGLa-AM1 to protect against cytokine-induced DNA damage, BRIN-BD11 cells were seeded at a density of $5 \times 10^{4}$ cells per well and exposed to a cytokine mixture $(200 \mathrm{U} / \mathrm{ml}$ tumor-necrosis factor- $\alpha, 20 \mathrm{U} / \mathrm{ml}$ interferon- $\gamma$, and $100 \mathrm{U} / \mathrm{ml}$ interleukin-1 $\beta)$ in the presence or absence of $[\mathrm{A} 14 \mathrm{~K}] \mathrm{PGLa}-\mathrm{AM} 1\left(10^{-6} \mathrm{M}\right)$ for $18 \mathrm{~h}$ at $37^{\circ} \mathrm{C}$ with GLP-1 $\left(10^{-6} \mathrm{M}\right)$ as a positive control. Cells were rinsed with $0.9 \%$ phosphate-buffered 
saline (PBS) and fixed using $4 \%$ paraformaldehyde. The cells were permeabilized with $0.1 \mathrm{M}$ sodium citrate buffer, $\mathrm{pH} 6.0$ at $94{ }^{\circ} \mathrm{C}$ for $20 \mathrm{~min}$. For effects on apoptosis, the cells were incubated with TUNEL reaction mixture (In situ Cell Death Detection Kit; Roche Diagnostics, Burgess Hill, UK) for $1 \mathrm{~h}$ at $37^{\circ} \mathrm{C}$ following the manufacturer's recommended procedure. Slides were viewed using a fluorescent microscope with $488 \mathrm{~nm}$ filter (Olympus System Microscope, model BX51; Southend-on-Sea, UK) and photographed by a DP70 camera adapter system.

To determine effects on proliferation, the cells were incubated in the presence or absence of [A14K]PGLa-AM1 $\left(10^{-6} \mathrm{M}\right)$ for $18 \mathrm{~h}$ at $37^{\circ} \mathrm{C}$ with GLP-1 $\left(10^{-6} \mathrm{M}\right)$ as a positive control and treated as above followed by staining with rabbit anti-Ki-67 primary antibody and subsequently with Alexa Fluor 594 secondary antibody (Abcam. Cambridge, UK) as previously described [25]. Proliferation frequency was determined in a blinded fashion and expressed as $\%$ of total cells analysed. Approximately 150 cells per replicate were analyzed.

\subsection{In vivo insulin release studies}

All animal experiments were carried out in accordance with the UK Animals (Scientific Procedures) Act 1986 and EU Directive 2010/63EU for animal experiments and approved by Ulster University Animal Ethics Review Committee. All necessary steps were taken to prevent any potential animal suffering. The procedure for determining the effects of glucose alone (18 $\mathrm{mmol} / \mathrm{kg}$ body weight) and in combination with [A14K]PGLa-AM1 (75 nmol/kg body weight) or [A20K]PGLa-AM1 (75nmol/kg body weight) in overnight fasted adult ( 8 week old), male, National Institutes of Health Swiss mice (Harlan Ltd, Bicester, UK ( $n=8)$ has been described 
previously [26]. Blood samples were collected before and after peptide administration at the different time points shown in Fig. 9.

In a second series of experiments, mice were maintained for 3 months on a high-fat diet as previously described $[19,27]$ and displayed clear manifestations of obesity, glucose intolerance and insulin resistance. Overnight fasted animals $(n=8)$ were injected intraperitoneally with glucose alone $(18 \mathrm{mmol} / \mathrm{kg}$ body weight) or together with [A14K]PGLaAM1 (75nmol/kg body weight) or [A20K]PGLa-AM1 (75nmol/kg body weight). Blood samples were collected and analyzed as described for the lean mice.

\subsection{Statistical Analysis}

Data are compared using unpaired Student's t test (non-parametric, with two-tailed P values and 95\% confidence interval) and one-way ANOVA with Bonferroni post-hoc test wherever applicable. Area under the curve (AUC) analysis is performed using the trapezoidal rule with baseline correction. Values are presented as mean \pm SEM. Results are considered significant if $p$ $<0.05$.

\section{Results}

\subsection{Effects of PGLa and analogues on insulin-release from BRIN-BD11 and 1.1B4 cells}

The glucose-responsive BRIN-BD111 cell line was generated by electrofusion of rat insulinoma-derived RINm5F cells with New England Deaconess Hospital rat pancreatic islet cells [13]. In the presence of the well-established insulin secretagogue, $10 \mathrm{mM}$ alanine, the rate 
of insulin release from BRIN-BD11 cells, increased approximately 8-fold (Fig. 1). Incubation with PGLa-AM1 produced a significant $(\mathrm{P}<0.05)$ stimulatory response at concentrations $\geq 100$ $\mathrm{nM}$ with a 4 -fold increase above the basal rate at $3 \mu \mathrm{M}$. The minimum concentrations producing a significant increase in secretion rate for the $[\mathrm{A} 14 \mathrm{~K}]$ analog $(10 \mathrm{pM})$ and for the $[\mathrm{A} 14 \mathrm{~K}](30 \mathrm{pM})$ were significantly less and the maximum response at $3 \mu \mathrm{M}$ were significantly greater the corresponding parameters for the native peptide (Fig. 1). At concentrations up to and including 3 $\mu \mathrm{M}$, neither PGLa-AM1 nor the $[\mathrm{A} 14 \mathrm{~K}]$ and the $[\mathrm{A} 20 \mathrm{~K}]$ peptides stimulated the release of LDH from the cells indicating that the integrity of the plasma membrane had not been compromised. In contrast, [A3K]PGLa-AM1, while potently stimulating insulin release (threshold concentration $3 \mathrm{pM}$ ), also produced an increase in the rate of release of LDH at concentrations $\geq$ $30 \mathrm{nM}$ (Supplementary Fig. 1). This cytotoxic analogue was not investigated further. Incubation of BRIN-BD11 cells with medium containing $30 \mathrm{mM} \mathrm{KCl}$ produced an increase in the rate of insulin release from $1.13 \pm 0.14 \mathrm{ng} / 10^{6}$ cells $/ 20 \mathrm{~min}$ in glucose alone to $9.48 \pm 0.60$ $\mathrm{ng} / 10^{6}$ cells $/ 20 \mathrm{~min}$. This rate was significantly $(\mathrm{P}<0.001)$ augmented to $12.24 \pm 0.92$ $\mathrm{ng} / 10^{6}$ cells $/ 20 \mathrm{~min}$ when incubations were carried out in the presence of $30 \mathrm{mM} \mathrm{KCl}+1 \mu \mathrm{M}$ [A14K]PGLa-AM1. 

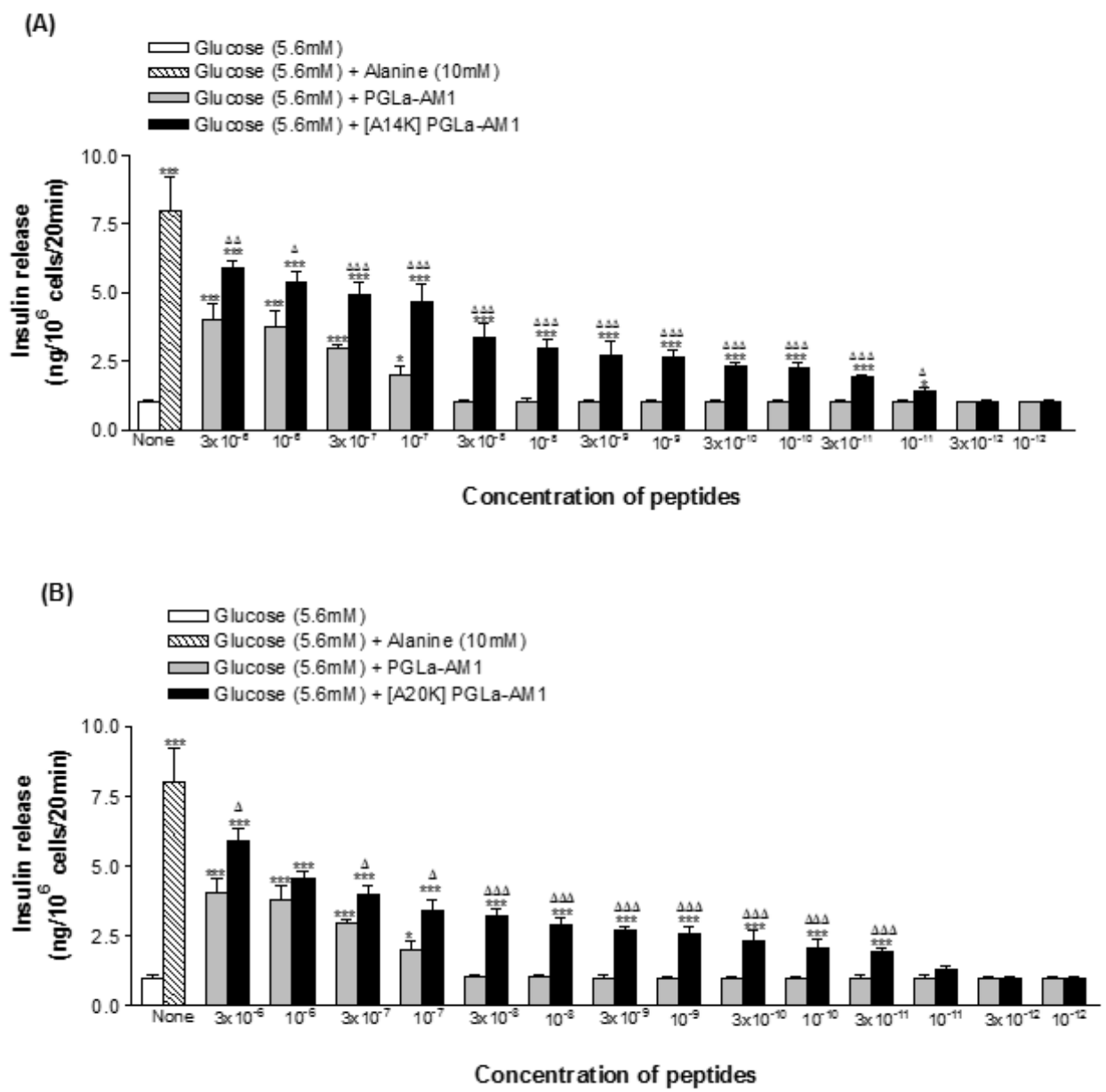

Fig. 1. Comparison of the effects of (A) [A14K]-PGLa-AM1 and (B) [A20K]PGLa-AM1 with PGLa-AM1 on insulin release from BRIN-BD11 cells Values are mean \pm SEM for $\mathrm{n}=8$.

$* \mathrm{P}<0.05, * * \mathrm{P}<0.01 * * * \mathrm{P}<0.001$ compared to $5.6 \mathrm{mM}$ glucose alone. ${ }^{\Delta} \mathrm{P}<0.05,{ }^{\Delta \Delta} \mathrm{P}<0.01$, ${ }^{\Delta \Delta \Lambda} \mathrm{P}<0.001$ compared to PGLa-AM1.

The 1.1B4 cell line was generated by electrofusion of freshly isolated human pancreatic islet cells with human PANC-1 epithelial cells [14]. It displays good responsiveness to glucose [28] and sensitivity to cytotoxic agents $[29,30]$ and so represents a useful surrogate for primary 
human $\beta$-cells [31]. As shown in Fig. 2, incubation of 1.1B4 cells with [A14K]PGLa-AM1 produced a significant $(\mathrm{P}<0.05)$ increase in the rate of insulin release at concentrations $\geq 30 \mathrm{pM}$ with an approximately 3 -fold increase at $3 \mu \mathrm{M}$. No significant increase in the rate of LDH release was observed at concentrations up to and including $3 \mu \mathrm{M}$. The response produced by the GLP-1 receptor agonist exenatide-4 $(10 \mathrm{nM})$ was 2-fold greater than the maximum response produced by $3 \mu \mathrm{M}[\mathrm{A} 14 \mathrm{~K}] \mathrm{PGLa}-\mathrm{AM} 1$.

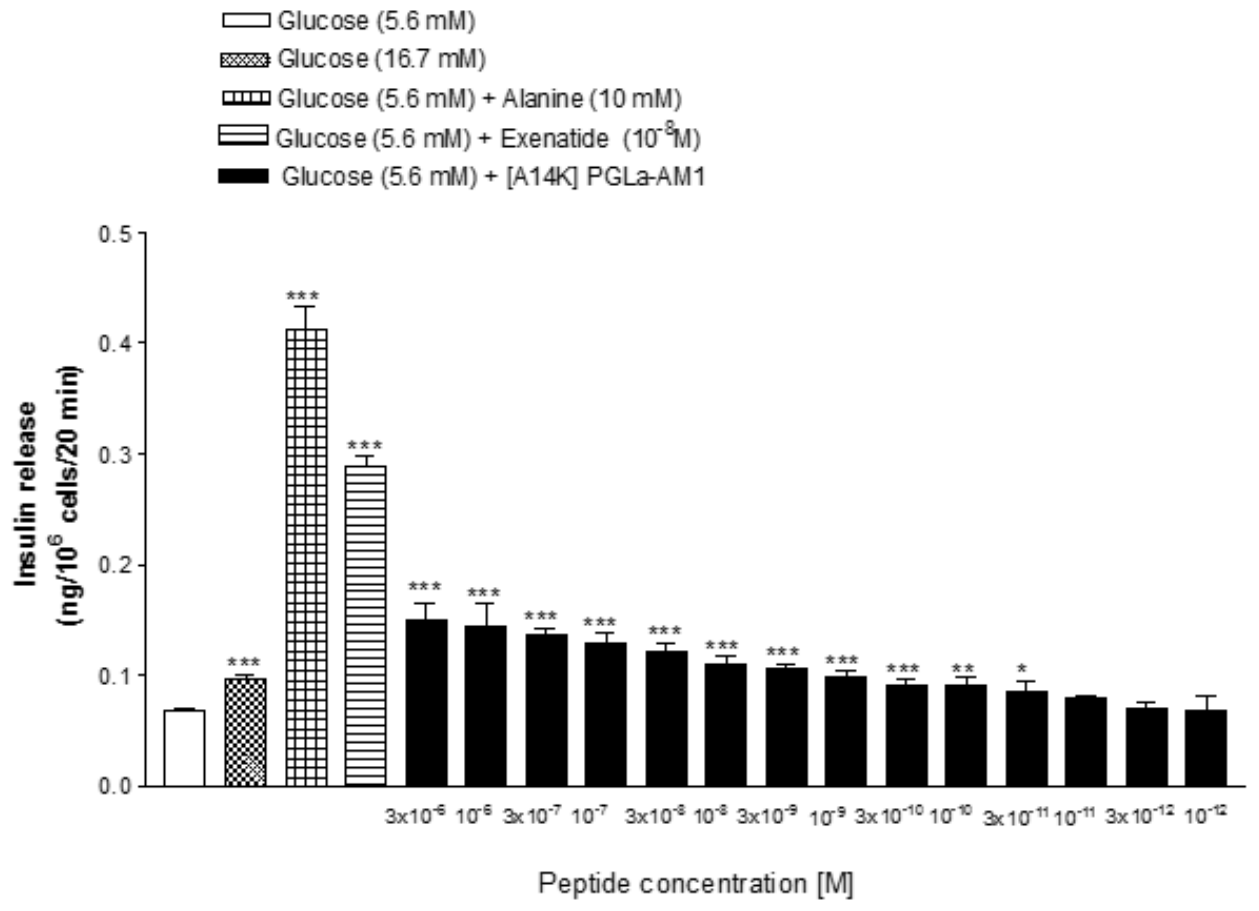

Fig. 2. Effects of [A14K]-PGLa-AM1 on insulin release from the 1.1B4 human-derived pancreatic $\beta$-cell line, Values are mean \pm SEM for $\mathrm{n}=8 . * \mathrm{P}<0.05, * * \mathrm{P}<0.01 * * * \mathrm{P}<0.001$ compared to $5.6 \mathrm{mM}$ glucose alone. 
3.2. Effects of [A14K]PGLa-AM1 and [A20K]PGLa-AM1 on insulin release from isolated mouse islets

In the presence of $16.7 \mathrm{mM}$ glucose, [A14K]PGLa-AM1 and [A20K]PGLa-AM1 produced a concentration-dependent increase in the rate of insulin secretion from dispersed mouse islets (Fig. 3). A significant stimulatory effects of [A14K]PGLa-AM1 was seen at concentrations $\geq 1 \mathrm{nM}$ while $[\mathrm{A} 20 \mathrm{~K}] \mathrm{PGLa}-\mathrm{AM} 1$ showed a significant stimulatory effect at 10 $\mathrm{nM}$. These effects were not accompanied by significant release of LDH from isolated islets at any concentration tested. The magnitude of the increase produced by $1 \mu \mathrm{M}$ concentration of each peptide was not significantly different from that produced by $1 \mu \mathrm{M}$ GLP-1. 
(A)

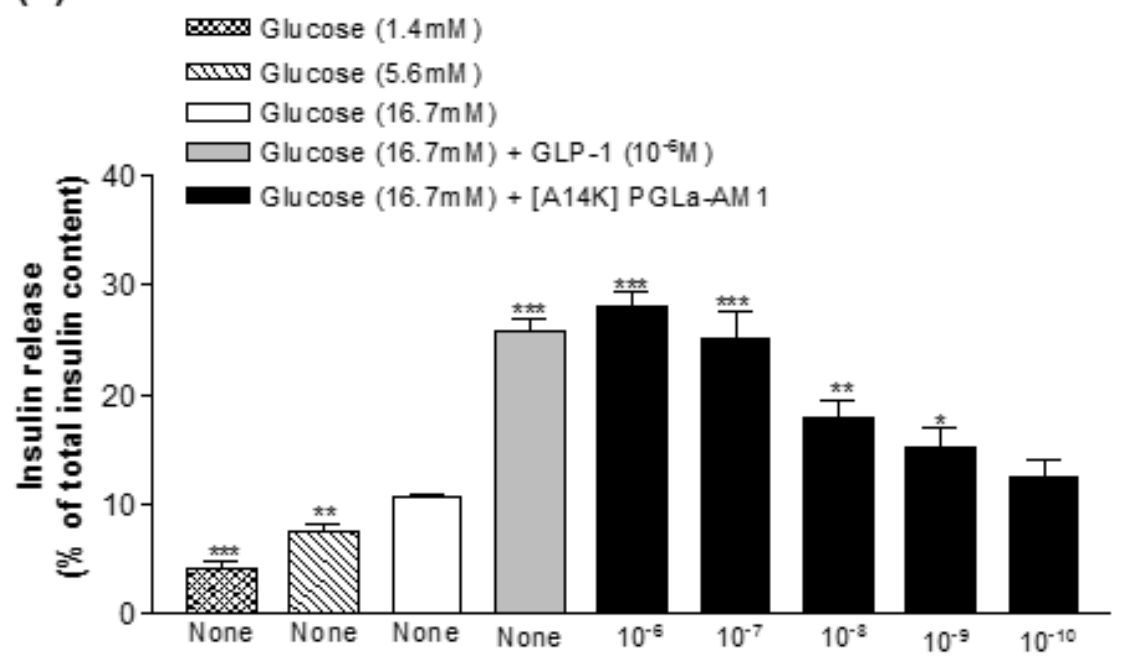

Concentration of peptide [M]

(B)

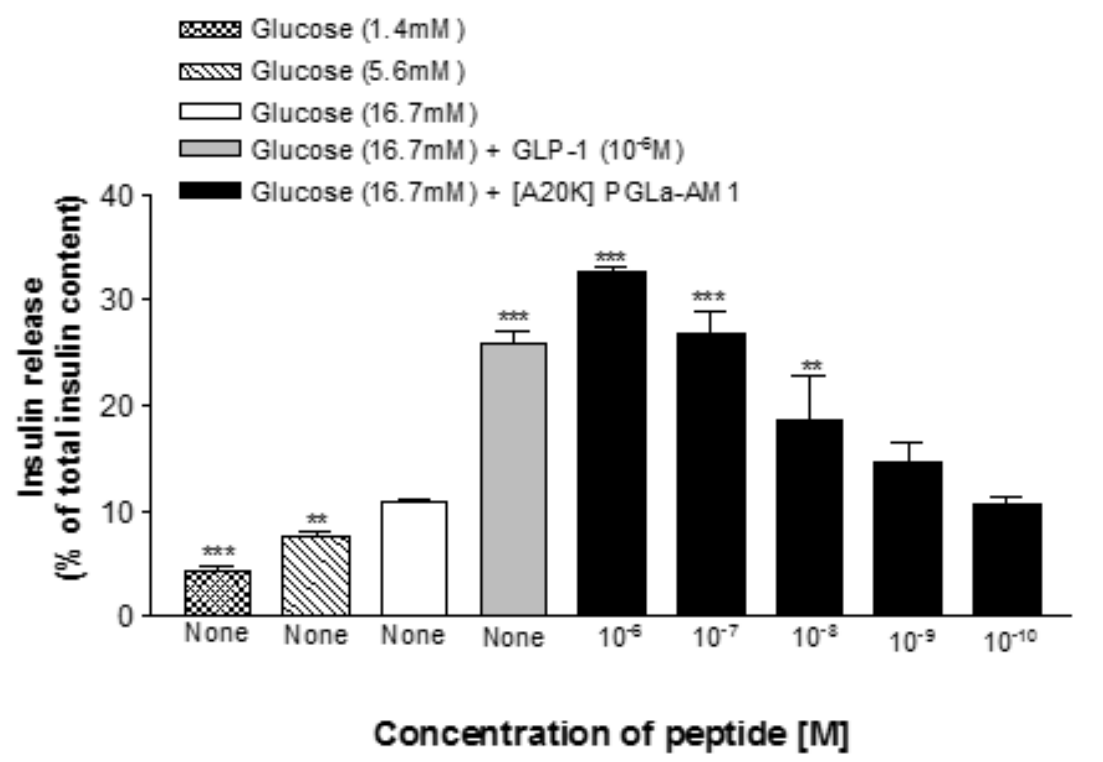

Fig. 3: Effects of (A) [A14K]PGLa-AM1 and (B) [A20K]PGLa-AM1 on insulin release from dispersed mouse islets. Values are mean \pm SEM $(\mathrm{n}=8) . * \mathrm{P}<0.05, * * \mathrm{P}<0.01, * * * \mathrm{P}<0.001$ compared to $16.7 \mathrm{mM}$ glucose alone 


\subsection{Effects of PGLa-AM1 and analogues on membrane depolarization and $\left[\mathrm{Ca}^{2+}\right] \mathrm{i}$}

A rapid and significant $(\mathrm{P}<0.01)$ membrane depolarisation was observed in BRIN-BD11 cells after treatment with PGLa-AM1 (Figs. 4A and B), [A14K] PGLa-AM1 (Fig. 4A) and [A20K] PGLa-AM1 (Fig. 4B. The magnitudes of the effects are compared with that produced by $30 \mathrm{mM} \mathrm{KCl}$ in Fig. 4C.
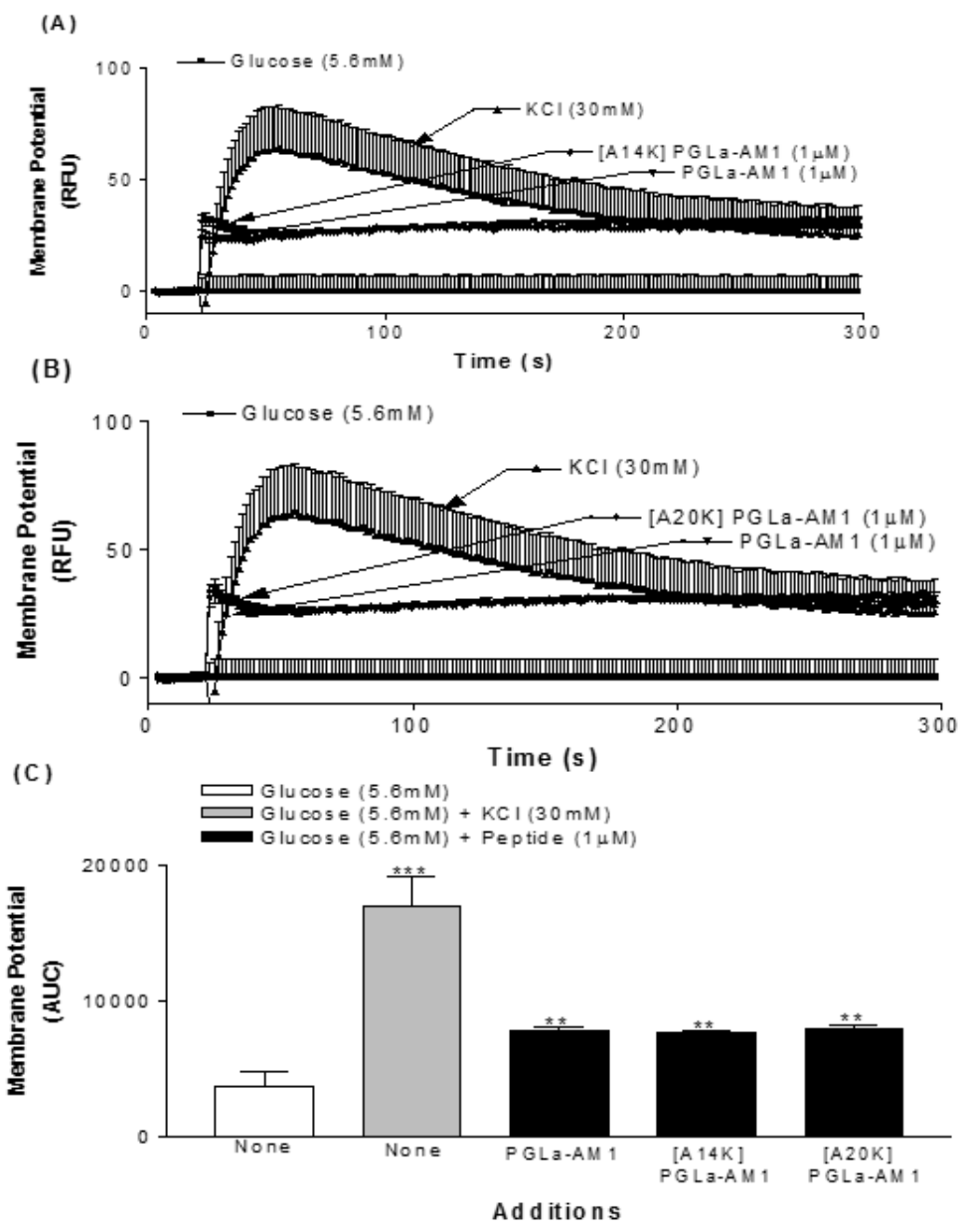

Fig. 4. Comparison of the effects of (A) [A14K]PGLa-AM1 and (B) [A20K]PGLa-AM1 with PGLa-AM1 on membrane potential in BRIN-BD11 cells expressed as relative fluorescence units, RFU and (C) integrated response (area under the curve). Values are mean $\pm \operatorname{SEM}(n=6)$. **P $<0.01, \quad * * * \mathrm{P}<0.001$ compared with $5.6 \mathrm{mM}$ glucose alone. 
The membrane depolarisation produced by the peptides was accompanied by a small but significant $(\mathrm{P}<0.05)$ increase in intracellular calcium concentration (Figs $5 \mathrm{~A}$ and $\mathrm{B})$. The magnitudes of the effects are compared with that produced by $10 \mathrm{mM}$ alanine in Fig. 5C. Patch clamp studies demonstrated that PGLa-AM1 had no significant effect on the $\mathrm{K}_{\mathrm{ATP}}$ current activated by diazoxide in BRIN-BD11 cells (Fig. 6). 


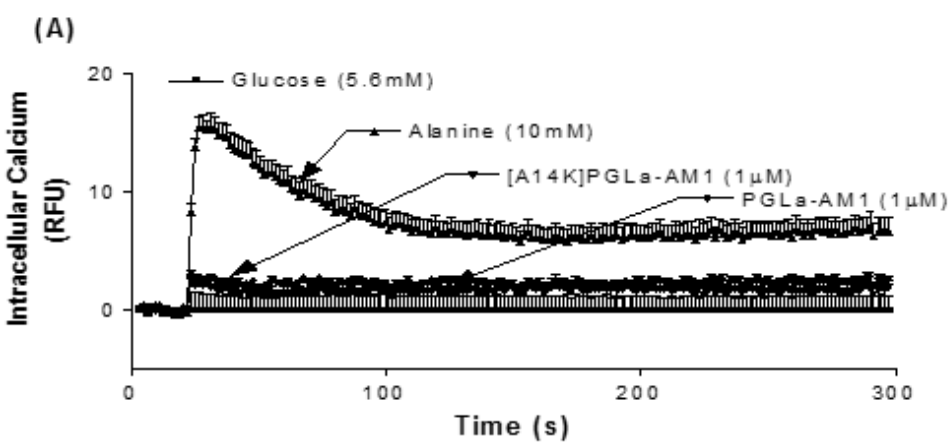

(B)
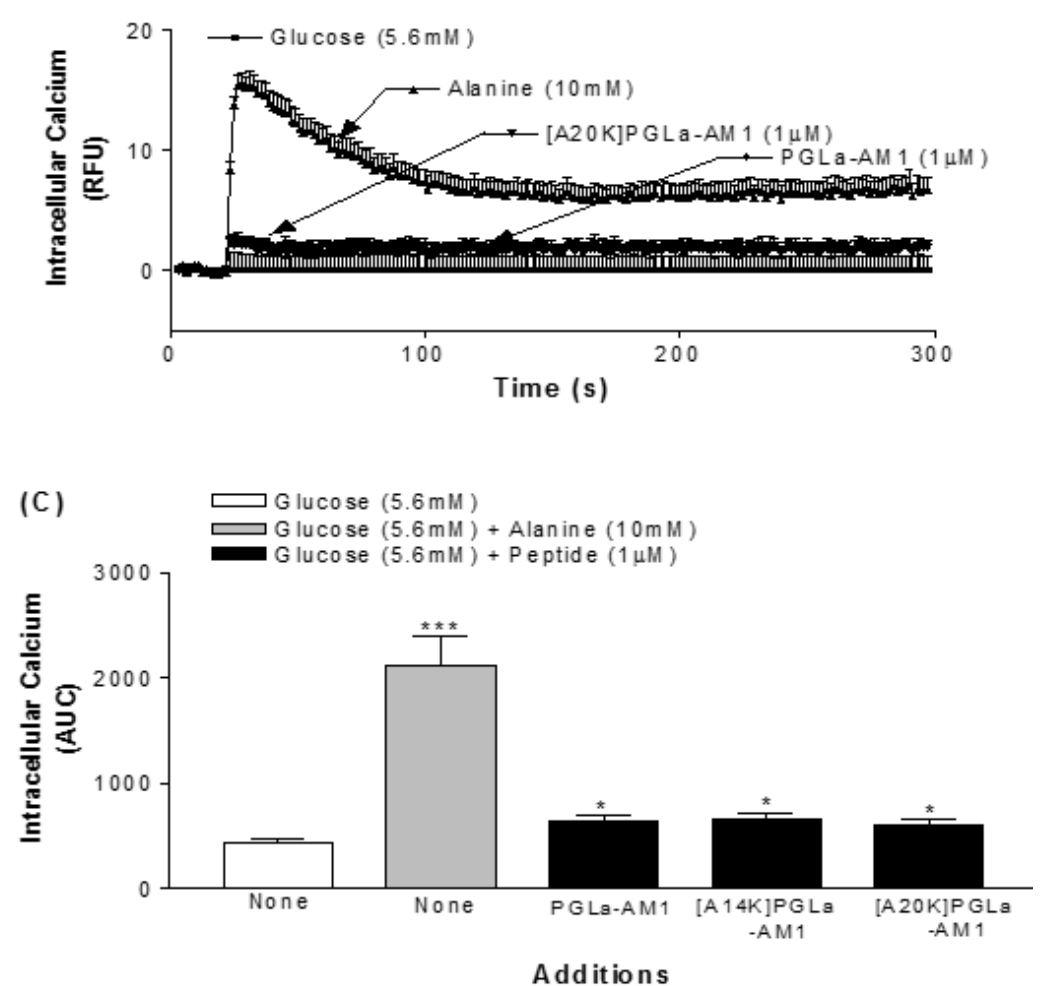

Fig. 5. Comparison of the effects of (A) [A14K]PGLa-AM1 and (B) [A20K]PGLa-AM1 with PGLa-AM1 on intracellular calcium concentrations in BRIN-BD11 cells expressed as (A) relative fluorescence units, RFU and (B) integrated response (area under the curve). Values are mean $\pm \operatorname{SEM}(\mathrm{n}=6) . * \mathrm{P}<0.05$, and $* * \mathrm{P}<0.01$ compared with $5.6 \mathrm{mM}$ glucose alone. 

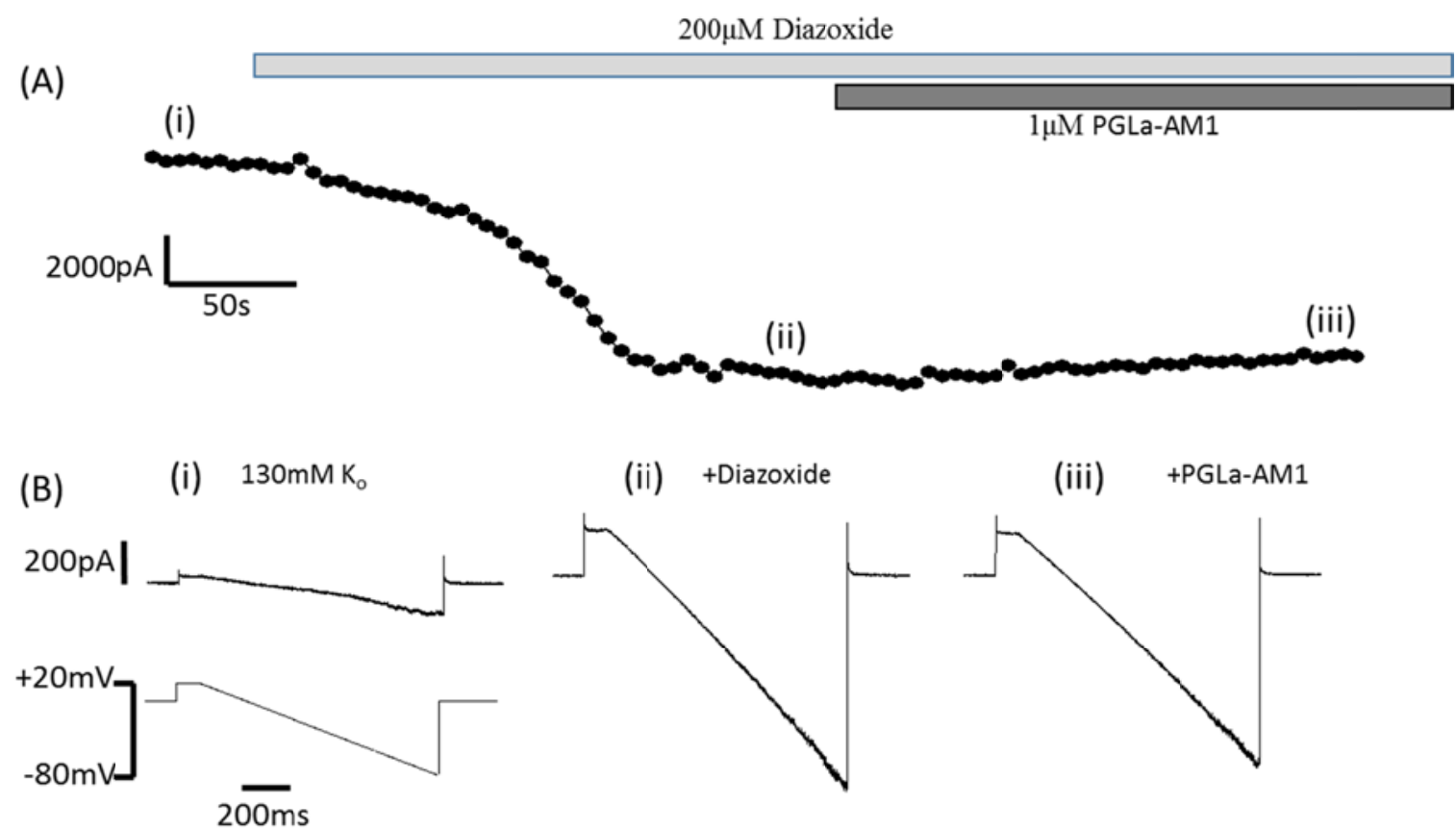

(C)

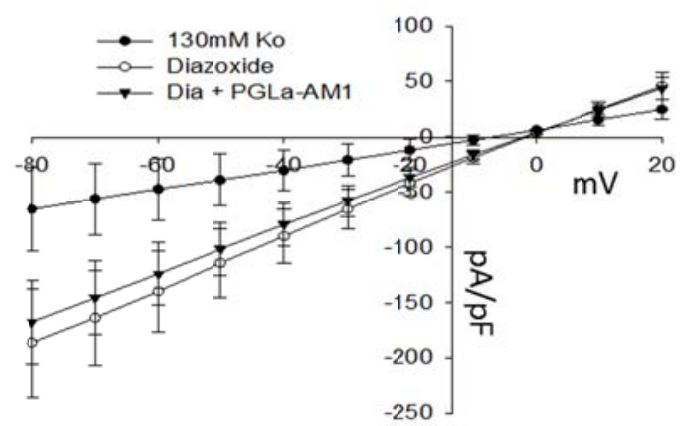

Fig. 6. (A) Membrane current recorded at $-80 \mathrm{mV}$ obtained during voltage ramp protocols applied every $5 \mathrm{~s}$, plotted before and during the application of the $\mathrm{K}_{\mathrm{ATP}}$ channel activator, diazoxide, in the absence and presence of PGLa-AM1. (B) Representative traces showing currents at points indicated on (A) generated by the application of the voltage ramp protocol illustrated in the lower panel ( $1 \mathrm{~s}$ ramp from +20 to $-80 \mathrm{mV}$ applied every $5 \mathrm{~s}$ ) under (i) control conditions (130 mM external $\left.\mathrm{K}^{+}\right)$, (ii) after application of diazoxide $(200 \mu \mathrm{M})$, and (iii) PGLaAM1 $(1 \mu \mathrm{M})$ in the continued presence of diazoxide. (C) Current-voltage relationships (mean \pm SEM) from 7 cells normalised to cell capacitance measured at $10 \mathrm{mV}$ intervals during the voltage ramp. 


\subsection{Effects of [A14K]PGLa-AM1 on intracellular concentrations of cyclic AMP}

In the presence of $200 \mu \mathrm{M}$ IBMX, [A14K]PGLa-AM $(1 \mu \mathrm{M})$ produced a significant $(\mathrm{P}<$ $0.01)$ increase in cAMP concentration in BRIN-BD11 cells compared to $5.6 \mathrm{mM}$ glucose suggesting an involvement of the PKA pathway (Fig. 7A). The magnitude of the increase was similar to that produced by $10 \mathrm{nM} \mathrm{GLP}-1$.

In a second series of experiments, the effects on [A14K]PGLa-AM1 stimulated insulin release of down-regulation of the PKA and PKC pathways by overnight incubation of BRINBD11 cells with forskolin and PMA respectively were investigated. When the activators were not present, the rates of insulin release produced by [A14K]PGLa-AM1, GLP-1, and CCK-8 were significantly $(\mathrm{P}<0.001)$ greater than that produced by $5.6 \mathrm{mM}$ glucose alone (Fig. 7B). The insulin stimulatory activities of [A14K]PGLa-AM1 and GLP-1, but not CCK-8, were completely abolished when the PKA pathway was down-regulated with $25 \mu \mathrm{M}$ forskolin.. In contrast, downregulation of the PKC pathway with $10 \mathrm{nM}$ PMA was without effect on the stimulatory activity of [A14K]PGLa-AM1 and GLP-1 but the effect of CCK-8 was abolished. Down-regulation of both the PKA and PKC pathways by forskolin + PMA abolished the stimulatory responses of all peptides tested (Fig. 7B). 

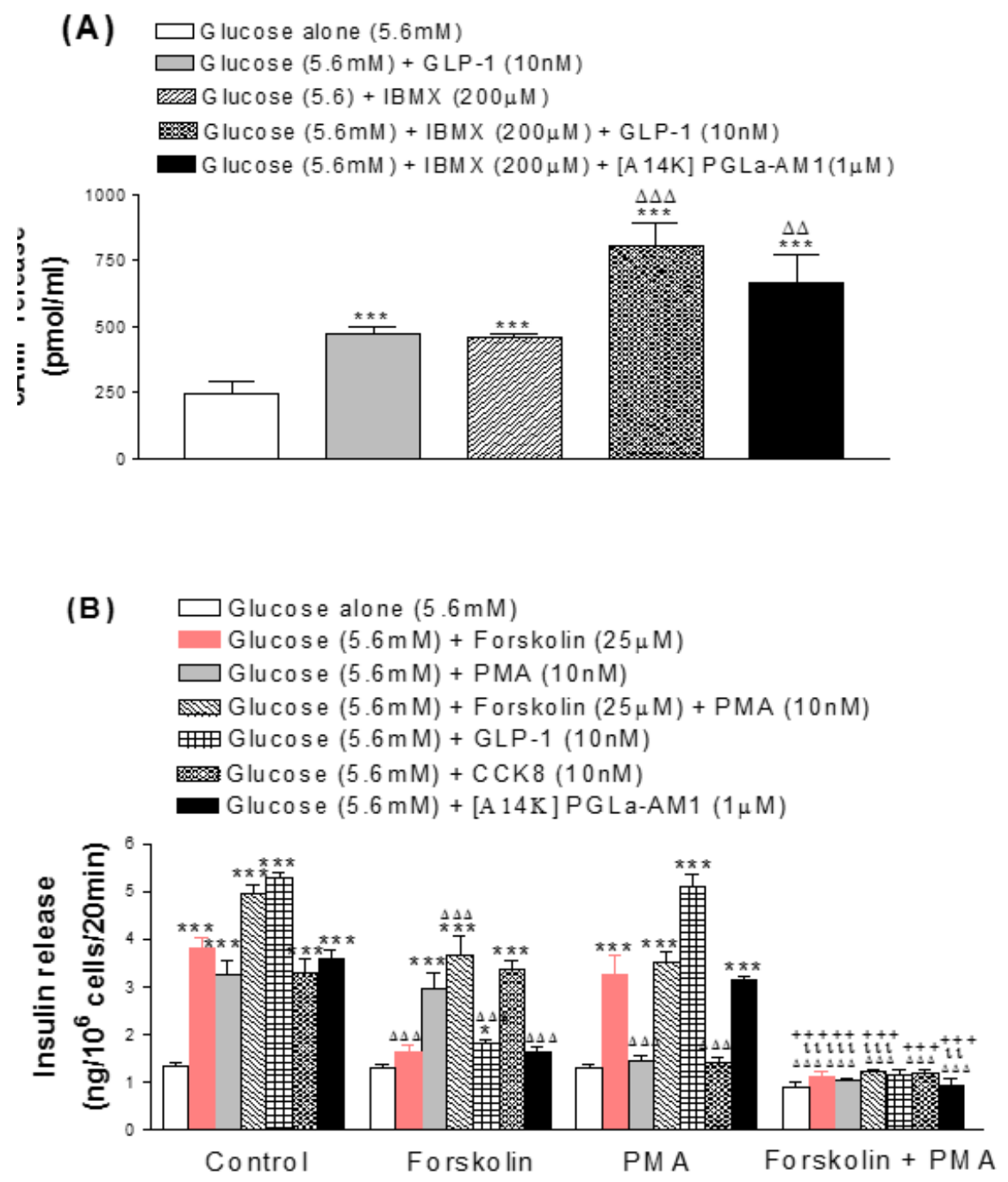

Fig. 7. (A) Effects of [A14K]PGLa-AM1 on cAMP production in BRIN-BD 11 cells. Values are mean \pm SEM for $\mathrm{n}=6 .{ }^{* * *} \mathrm{P}<0.001$ compared to $5.6 \mathrm{mM}$ glucose alone. ${ }^{\Delta \Delta} \mathrm{P}<0.01,{ }^{\Delta \Delta \Delta} \mathrm{P}<0.001$ compared to $5.6 \mathrm{mM}$ glucose + IBMX. (B) Effects of [A14K]PGLa-AM1 on insulin release from BRIN-BD11 cells following down regulation of the PKA and PKC pathways by overnight culture with $25 \mu \mathrm{M}$ forskolin or $10 \mathrm{nM}$ PMA respectively. Values are mean $\pm \mathrm{SEM}$ for $\mathrm{n}=8$. ***P $<0.001$ compared to $5.6 \mathrm{mM}$ glucose, ${ }^{\Delta \Delta \Delta} \mathrm{P}<0.001$ compared to incubation under standard culture conditions ${ }^{\phi \phi} \mathrm{P}<0.01,{ }^{\phi \phi \phi} \mathrm{P}<0.001$ compared to incubation with forskolin , ${ }^{++} \mathrm{P}<0.01,{ }^{+++} \mathrm{P}<0.001$, compared to respective incubation with PMA. 
3.6. Effects of [A14K]PGLa-AM1 on apoptosis and cell proliferation in BRIN-BD11 cells

As shown in Fig. 8A, neither [A14K]PGLa-AM1 $(1 \mu \mathrm{M})$ nor GLP-1(1 $\mu \mathrm{M})$ alone affected the number of BRIN-BD11 cells exhibiting DNA damage as measured by TUNEL assay. Incubation with a mixture of pro-inflamatory cytokines significantly $(\mathrm{P}<0.001)$ increased the number of apoptotic cells by 3.7-fold. Co-incubation of the cells with [A14K]PGLa-AM1 and the cytokine mixture significantly $(\mathrm{P}<0.001)$ reduced the number of apoptotic cells by $49 \%$. This value was comparable to the degree of protection ( $48 \%$ reduction) provided by the same concentration of GLP-1. As shown in Fig. 8B, $1 \mu \mathrm{M}$ [A14K]PGLa-AM1 significantly $(\mathrm{P}<$ 0.001 ) stimulated proliferation of BRIN-BD11 cells by an amount ( $42 \%$ increase) that was comparable to that produced by $1 \mu \mathrm{M}$ GLP-1 (43\% increase). 
(A) $\square$ control

Cytokine treated cells

GLP-1 $\left(10^{-6} \mathrm{M}\right)$ treated cells

¿ GLP-1 $\left(10^{-6} \mathrm{M}\right)$ treated cells $+C$ ytokine treated cells

㘞田 [A14K] P GLa-AM1 $\left(10^{-6} M\right)$ treated cells

m四 [A14K] PGLa-AM1 $\left(10^{-6} \mathrm{M}\right)$ treated cells +Cytokine treated cells

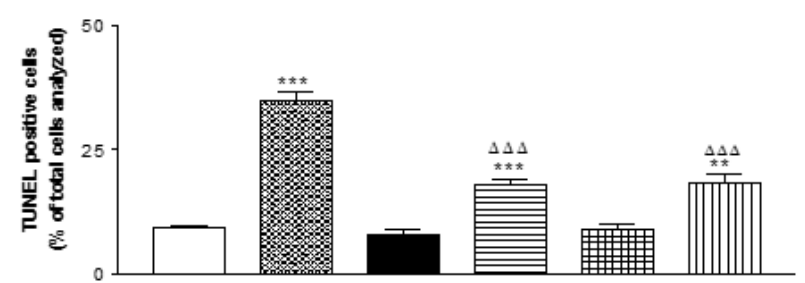

(B)

$\square$ Control

GLP-1 $\left(10^{-6} \mathrm{M}\right)$ treated cells

$\square$ [A14K] PGLa-AM1 (10-6 M) treated cells

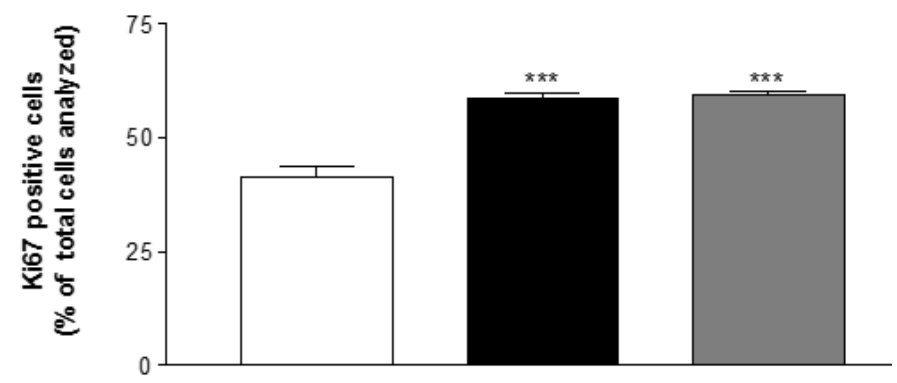

Fig, 8. (A) Comparison of the effects of [A14K]PGLa-AM1 $(1 \mu \mathrm{M})$ and GLP-1 $(1 \mu \mathrm{M})$ on protection against cytokine-induced apoptosis in BRIN-BD11 cells . ${ }^{* * *} \mathrm{P}<0.001$ compared to incubation in culture medium alone, ${ }^{\Delta \Delta \Delta} \mathrm{P}<0.001$ compared to incubation in cytokinecontaining medium. (B) Comparison of the effects of [A14K]PGLa-AM1 $(1 \mu \mathrm{M})$ and GLP-1 (1 $\mu \mathrm{M})$ on proliferation of BRIN-BD11 cells ${ }^{* * *} \mathrm{P}<0.001$ compared to incubation in culture medium alone 


\subsection{Effects of PGLa analogues on insulin concentrations and glucose tolerance in lean and high-fat fed mice}

Administration of the peptides did not produce any apparent adverse effects in the animals. Plasma glucose concentrations in lean mice receiving glucose plus [A14K]PGLa-AM1 (75nmol/kg body weight) (Fig. 9A) or glucose plus [A20K]PGLa-AM1 (75nmol/kg body weight) (Fig. 9B) were not significantly different at any time point compared with animals receiving glucose only. However, the integrated response of plasma glucose (area under the curve $)$ of the two peptides was significantly $(\mathrm{P}<0.05)$ less after administration of vehicle only (Fig. 9C). Plasma insulin concentrations were significantly $(\mathrm{P}<0.05)$ higher at 15 min after glucose administration in animals receiving [A14K]PGLa-AM1 (Fig. 9D) or [A20K]PGLa-AM1 (Fig. 9E) and the integrated response (total amount of insulin released over $60 \mathrm{~min}$ ) was significantly greater $(\mathrm{P}<0.05)$ for both peptides (Fig. 9F).

In a second series of experiments using the same protocol, plasma glucose concentrations in high-fat fed mice receiving intraperitoneal A14K]PGLa-AM1) or [A20K]PGLa-AM1 were also not significantly different at any time point compared with injection of glucose alone but the integrated plasma glucose response area under the curve) was significantly $(\mathrm{P}<0.05)$ greater than after administration of both peptides (Supplementary Figure 2). Similarly, plasma insulin concentrations were significantly $(\mathrm{P}<0.05)$ higher at $15 \mathrm{~min}$ after glucose administration in animals receiving [A14K]PGLa-AM1 and the integrated insulin responses were significantly greater for $[\mathrm{A} 14 \mathrm{~K}] \mathrm{PGLa}-\mathrm{AM} 1(\mathrm{P}<0.01)$ and for $[\mathrm{A} 20 \mathrm{~K}] \mathrm{PGLa}-\mathrm{AM} 1(\mathrm{P}<0.05)$. 
(A)

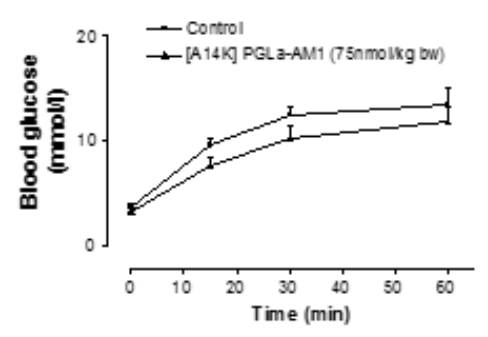

(B)

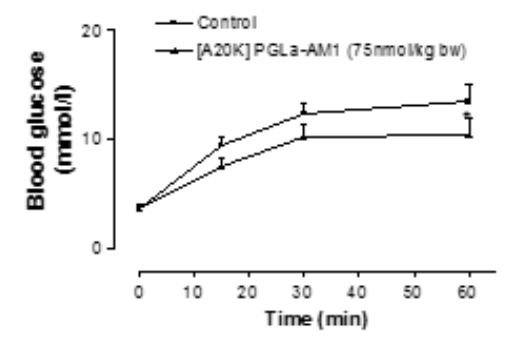

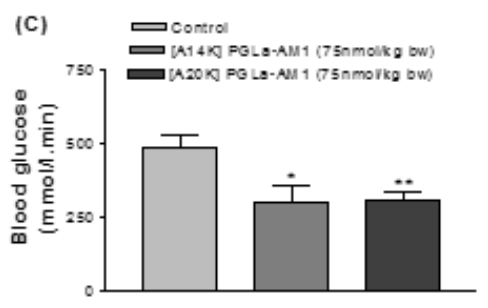
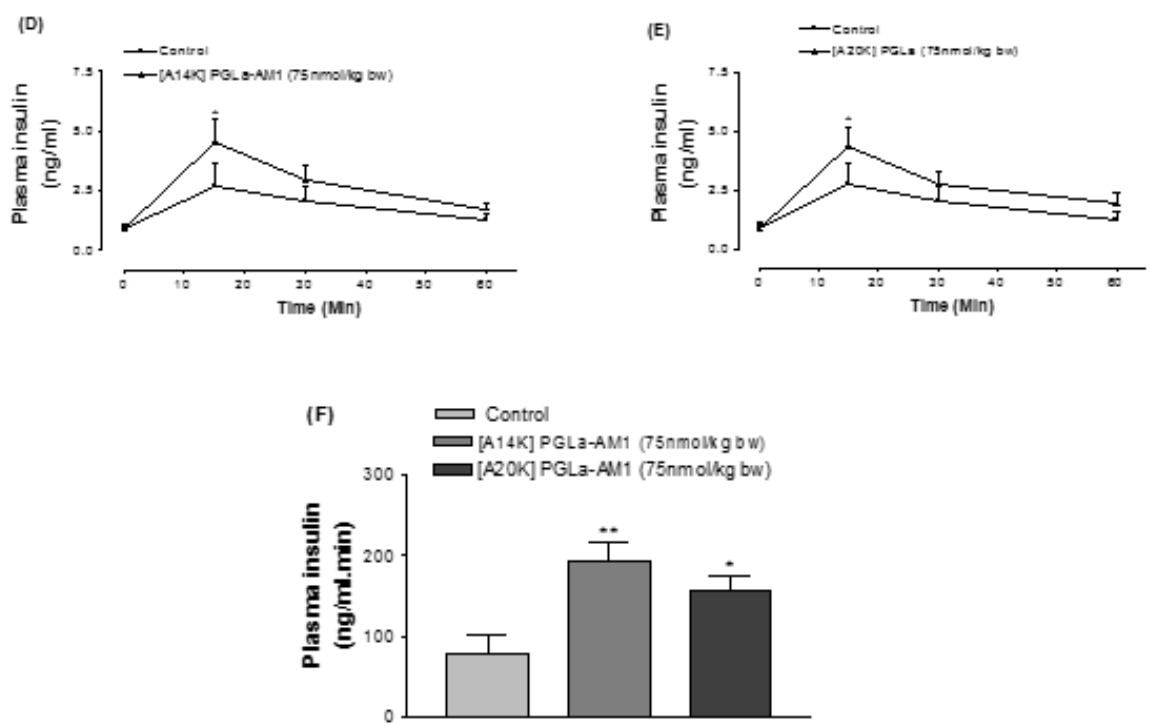

Fig. 9. Effects of acute administration of [A14K]PGLa-AM1 (75 nmol/kg body weight) and [A20K]PGLa-AM1 (75 nmol/kg body weight) on blood glucose (panels A-C) and plasma insulin (panels D-F) concentrations in lean mice after intraperitoneal injection of glucose $((18 \mathrm{mmol} / \mathrm{kg}$ body weight). Values are mean $\pm \operatorname{SEM}(\mathrm{n}=8) .{ }^{*} \mathrm{P}<0.05, * * \mathrm{P}<0.01$ compared to glucose alone. 


\section{Discussion}

The global pandemic of T2DM has intensified the search for naturally occurring compounds that may be developed into therapeutic agents that maintain normoglycaemia and prevent or retard the development of the complications associated with the disease. Particular attention has been directed towards compounds that stimulate insulin release (sulphonyureas and incretins) [32] and long acting peptide analogues based upon the structure of the physiologically important incretin GLP-1 have been widely adopted in clinical practice [33]. Norepinephrinestimulated skin secretion of frogs belonging to the family Pipidae, comprising the genera Hymenochirus, Pipa, Pseudhymenochirus and Xenopus [1], contain a diverse range of peptides whose primary function is probably host-defense (reviewed in [7]). Several such peptides have been shown to stimulate insulin release from BRIN-BD11 cells at concentrations that are appreciably less than those required to kill microorganisms. These include CPF-6 from Xenopus laevis [34], CPF-SE1 from Xenopus epitropicalis [34], hymenochirin-1B from Hymenochirus boettgeri [5] and pseudhymenochirin-1P and -2a from Pseudhymenochirus merlini [20]. In this study, PGLa-AM1 and its [A14K] and [A20K] analogues stimulate the rate of insulin release in vitro by BRIN-BD11 rat clonal $\beta$-cells, by the 1.1B4 human-derived pancreatic $\beta$-cell line, and by dispersed mouse islets at concentrations that are not toxic to the cells. Taken together, these results suggest that host-defense peptides from frogs belonging to the Pipidae show potential for development into therapeutically valuable agents for treatments of patients with T2DM.

The ability of a cationic, $\alpha$-helical peptide to permeabilize the plasma membrane of a mammalian cell is dependent on complex interactions between conformation, cationicity, 
hydrophobicity, and amphipathicity. While PGLa-AM1 and the [A14K] and the [A20K] analogues were not toxic to BRIN-BD11 cells at concentrations up to $3 \mu \mathrm{M}$, incubation with [A3K]PGLa-AMI in concentrations as low as $30 \mathrm{nM}$ led to an increase in the rate of release of the cytosolic enzyme LDH indicative of loss of integrity of the plasma membrane. The changes in cationicity and hydrophobicity produced by the L-Ala $\rightarrow$ L-Lys substitutions are the same in the three analogues. Studies with a range of naturally occurring and model peptides [35-37] have shown that small changes in hydrophobic moment (a semi-quantitative measure of the amphipathicity of $\alpha$-helical peptides) may produce major changes in cytolytic activity against microorganisms and mammalian cells, such as erythrocytes. In the absence of data derived from NMR measurements, one may speculate that the $\mathrm{Ala}^{3} \rightarrow$ Lys substitution produces a substantial change in the conformation of the $\alpha$-helical domain that results in a change in the degree of amphipathicity.

On the basis of previous studies, cationic insulinotropic peptides from frog skin may be divided into two classes. The peptides alyteserin-2a, tigerinin-1R, CPF-6, esculentin-2CHa and peptides of the temporin family produce cellular depolarization and increase intracellular calcium concentration in BRIN-BD11 cells (reviewed in [4]). In contrast, the insulin-releasing actions of brevinin-2GUb, phylloseptin-L2, pseudin-2, and hymenochirin-1b do not appear to involve membrane depolarization or an increase in intracellular $\mathrm{Ca}^{2+}$ concentrations [4]. PGLaAM1, when incubated with BRIN-BD11 cells, produces membrane depolarization (Fig. 4) and a small but significant increase in intracellular calcium concentration (Fig. 5) but patch-clamp studies (Fig. 6) have shown that the insulin-releasing effects of the peptide are probably not mediated by a pathway which involves closure of ATP-sensitive potassium channels and opening of voltage-dependent calcium channels. Consistent with this proposal, the rate of insulin release 
from BRIN-BD11 cells produced by a depolarizing stimulus $(30 \mathrm{mM} \mathrm{KCl})$ was augmented by 1 $\mu \mathrm{M}$ PGLa-AM1 suggesting an involvement of an, as yet uncharacterized, $\mathrm{K}_{\mathrm{ATP}}$ channelindependent pathway.

Incubation of BRIN-BD11 cells with GLP-1 stimulates cAMP production and it was proposed that signaling via the protein kinase A (PKA) pathway may contribute to the modulation of $\mathrm{K}_{\mathrm{ATP}}$ independent secretory pathway triggered by the peptide [24]. PGLaAM1also increases intracellular cAMP concentration in BRIN-BD11 cells and down-regulation of PKA pathway by overnight incubation with forskolin abolishes the insulinotropic activity of the peptide (Fig. 7). In contrast, down-regulation of the protein kinase $\mathrm{C}$ pathway by phorbol 12myristate 13 -acetate, while attenuating the insulinotropic action of CCK-8, had no significant effect on the rate of insulin release produced by PGLa-AM1. PKA activation causes a marked increase in L-type $\mathrm{Ca}^{2+}$ currents in cardiac myocytes [38] and it is tempting to speculate that the increase in cAMP concentrations produced by PGLa-AM1 increases the open probability of Ltype channels in BRIN-BD11 cells resulting in the observed depolarisation and small increase in $\left[\mathrm{Ca}^{2+}\right]$

As well as lowering blood glucose levels by stimulating insulin secretion, GLP-1 exerts other beneficial effects on glucose homeostasis by suppression of appetite, reduction in plasma glucagon concentrations, and improvement of glucose uptake in peripheral tissues. In addition, GLP-1 $[39,40]$ and GLP-1 receptor agonists $[41,42]$ stimulate $\beta$-cell proliferation and regeneration, and protect against $\beta$-cell damage leading to increased $\beta$-cell mass and improved $\beta$ cell function. This study has shown that [A14K]PGLa-AM1 shows beta-cell proliferative activity comparable to that of GLP-1 when tested in BRIN-BD11 cells and is equally effective in protecting the cells against cytokine-induced apoptosis (Fig 8). A role for pro-inflammatory 
cytokines in promoting $\beta$-cell apoptosis is well established $[43,44]$. $\beta$-cell mass is determined by the relative rates of replenishment and death and T2DM involves a gradual decline in both the function and mass of the $\beta$-cells. Consequently, agents such as [A14K]PGLa-AM1, which not only stimulate insulin release but also stimulate $\beta$-cell proliferation and reduce $\beta$-cell loss, are attractive from a therapeutic prospective.

Finally, the study has shown that [A14K]PGLa-AM1 and [A20K] PGLa-AM1 display anti-hyperglycaemic properties in vivo when administered acutely to lean mice (Fig. 9). The glucose-lowering and insulin-releasing effects were significant and the magnitude of the changes were comparable those observed following similar administration of equimolar doses of the frog skin peptides phylloseptin-L2 [25], and brevinin-2GUb [45]. The high-fat fed mouse presents with obesity, hyperglycaemia, and insulin resistance and so is a useful model to study the development of metabolic syndrome and Type 2 diabetes [46,47]. The present study has demonstrated that [A14K]PGLa-AM1 also lowered blood glucose and enhanced insulin secretion in high-fat fed mice.

In conclusion, PGLa-AM1 and its more cationic $[\mathrm{A} 14 \mathrm{~K}]$ and $[\mathrm{A} 20 \mathrm{~K}]$ analogues stimulate the rate of insulin release from the rat BRIN-BD11 and human 1.1B4 established cell lines and are equipotent with GLP-1 in stimulating insulin release from isolated mouse islets. In addition, [A14K]PGLa-AM1 protects BRIN-BD1 1 clonal $\beta$-cells against cytokine-induced apoptosis and stimulates proliferation. These encouraging results warrant further studies to develop long-acting analogues of PGLa-AM1, for example by incorporating D-amino acids and/or a fatty acid moetiy into the molecule, to stimulate the function and arrest the $\beta$-cell degeneration seen in patients with long-standing T2DM. 


\section{Acknowledgements}

Funding for this study was provided by a project grant from Diabetes UK and by the University of Ulster Research Strategy Funding.

\section{Conflict of Interest}

No conflict of interest declared 


\section{References}

1. Frost DR. Amphibian species of the world: an online reference. Version 6.0 American Museum of Natural History, New York, USA. Electronic database accessible at http://research.amnh.org/ herpetology/ amphibia/index.php.

2. Conlon JM. 2011. The contribution of skin antimicrobial peptides to the system of innate immunity in anurans. Cell Tissue Res. 2011; 343: 201-212.

3. Xu X, Lai R. The chemistry and biological activities of peptides from amphibian skin secretions. Chem. Rev. 2015 115: 1760-1846.

4. Conlon JM., Mechkarska M, Lukic ML, Flatt PR. Potential therapeutic applications of multifunctional host-defense peptides from frog skin as anti-cancer, anti-viral, immunomodulatory, and anti-diabetic agents. Peptides 2014; 57: 67-77.

5. Owolabi BO, Ojo OO, Srinivasan DK, Conlon JM, Flatt PR, Abdel-Wahab YH. In vitro and in vivo insulinotropic properties of the multifunctional frog skin peptide hymenochirin-1B: a structure-activity study. Amino Acids 2016; 48: 535-547.

6. Gibson BW, Poulter L, Williams DH, Maggio JE Novel peptide fragments originating from PGLa and the caerulein and xenopsin precursors from Xenopus laevis. J. Biol. Chem. 1986; 261: 5341-5349.

7. Conlon JM, Mechkarska M .Host-defense peptides with therapeutic potential from skin secretions of frogs from the family Pipidae. Pharmaceuticals (Basel) 2014; 7: 58-77.

8. Glattard E, Salnikov ES, Aisenbrey C, Bechinger B. Investigations of the synergistic enhancement of antimicrobial activity in mixtures of magainin 2 and PGLa. Biophys. Chem. 2016; 210: 35-44. 
9. Zerweck J, Strandberg E, Bürck J, Reichert J, Wadhwani P, Kukharenko O, Ulrich AS. Homo- and heteromeric interaction strengths of the synergistic antimicrobial peptides PGLa and magainin 2 in membranes. Eur. Biophys. J. 2016; 45: 535-547.

10. Conlon JM, Al-Ghaferi N, Ahmed E, Meetani MA, Leprince J, Nielsen PF Orthologs of magainin, PGLa, procaerulein-derived, and proxenopsin-derived peptides from skin secretions of the octoploid frog Xenopus amieti (Pipidae). Peptides 2010; 31: 989-994.

11. McLean DT, McCrudden MT, Linden GJ, Irwin CR, Conlon JM, Lundy FT. Antimicrobial and immunomodulatory properties of PGLa-AM1, CPF-AM1, and magainin-AM1: potent activity against oral pathogens. Regul. Pept. 2014; 194-195: 6368.

12. Ojo OO, Conlon JM, Flatt PR, Abdel-Wahab YH. Frog skin peptides (tigerinin-1R, magainin-AM1, -AM2, CPF-AM1, and PGLa-AM1) stimulate secretion of glucagon-like peptide 1 (GLP-1) by GLUTag cells. Biochem. Biophys. Res. Commun. 2013; 431: 14-18.

13. McClenaghan NH, Barnett CR, Ah-Sing E, Abdel-Wahab YHA, O'Harte FP, Yoon TW, Swanston-Flatt SK, Flatt PR. Characterization of a novel glucose-responsive insulinsecreting cell line, BRIN-BD11, produced by electrofusion. Diabetes 1996; 45: $1132-$ 1140.

14. McCluskey JT, Hamid M, Guo-Parke H, McClenaghan NH, Gomis R, Flatt PR. Development and functional characterization of insulin-releasing human pancreatic beta cell lines produced by electrofusion. J. Biol. Chem. 2011; 286: 21982-21992.

15. Avan C, Hall D, Katritzky AR. Peptidomimetics via modifications of amino acids and peptide bonds. Chem. Soc. Rev. 2014; 43: 3575-3594. 
16. Wieprecht T, Apostolov O, Beyermann M, Seelig J. Membrane binding and pore formation of the antibacterial peptide PGLa: thermodynamic and mechanistic aspects. Biochemistry 2000: 39: 442-452.

17. Muñoz V, Serrano L. Elucidating the folding problem of helical peptides using empirical parameters. Nature Struct. Biol. 1994; 1: 399-409.

18. Abdel-Wahab YHA, Power GJ, Ng MT, Flatt PR, Conlon JM. Insulin-releasing properties of the frog skin peptide pseudin-2 and its $\left[\mathrm{Lys}^{18}\right]$-substituted analogue. Biol.Chem 2008; 389: 143-148.

19. Abdel-Wahab YHA, Patterson S, Flatt PR, Conlon JM. Brevinin-2-related peptide and its [D4K] analogue stimulate insulin release in vitro and improve glucose tolerance in mice fed a high fat diet. Horm. Metab. Res. 2010; 42: 652-656.

20. Manzo G, Scorciapino MA, Srinivasan D, Attoub S, Mangoni ML, Rinaldi AC, Casu M, Flatt PR, Conlon JM. Conformational analysis of the host-defense peptides pseudhymenochirin- $1 \mathrm{~Pb}$ and $-2 \mathrm{~Pa}$ and design of analogues with insulin-releasing activities and reduced toxicities. J. Nat. Prod. 2015; 78: 3041-3048.

21. Flatt PR, Bailey CJ. Abnormal plasma glucose and insulin responses in heterozygous lean (ob/+) mice. Diabetologia 1981; 20: 573-577.

22. Goto M, Maki T, Kiyoizumi T, Satomi S, Monaco AP. An improved method for isolation of mouse pancreatic islets. Transplantation 1985; 40: 437-438.

23. Ojo OO, Srinivasan DK, Owolabi BO, McGahon MK, Moffett RC, Curtis TM, Conlon JM, Flatt PR, Abdel-Wahab YH. Molecular mechanisms mediating the beneficial metabolic effects of [Arg4]tigerinin-1R in mice with diet-induced obesity and insulin resistance. Biol. Chem. 2016; 397: 753-764. 
24. McClenaghan NH, Flatt PR, Ball AJ. Actions of glucagon-like peptide-1 on KATP channel-dependent and -independent effects of glucose, sulphonylureas and nateglinide. $J$. Endocrinol. 2006; 190: 889-896.

25. Khan D, Vasu S, Moffett RC, Irwin N, Flatt PR. Islet distribution of Peptide YY and its regulatory role in primary mouse islets and immortalised rodent and human beta-cell function and survival. Mol. Cell. Endocrinol. 2016; 436: 102-113.

26. Abdel-Wahab YH, Power GJ, Flatt PR, Woodhams DC, Rollins-Smith LA, Conlon JM. A peptide of the phylloseptin family from the skin of the frog Hylomantis lemur (Phyllomedusinae) with potent in vitro and in vivo insulin-releasing activity. Peptides 2008; 29: 2136-2143.

27. Ojo OO, Abdel-Wahab YH, Flatt PR, Mechkarska M, Conlon JM. Tigerinin-1R: a potent, non-toxic insulin-releasing peptide isolated from the skin of the Asian frog, Hoplobatrachus rugulosus. Diabetes Obes. Metab. 2011; 13: 1114-1122.

28. Vasu S, McClenaghan NH, McCluskey JT, Flatt PR. Cellular responses of novel human pancreatic $\beta$-cell line, 1.1B4 to hyperglycemia. Islets 2013; 5: 170-177.

29. Vasu S, McClenaghan NH, McCluskey JT, Flatt PR. Mechanisms of toxicity by proinflammatory cytokines in a novel human pancreatic beta cell line, 1.1B4. Biochim. Biophys. Acta. 2014; 1840: 136-145.

30. Vasu S, McClenaghan NH, Flatt PR. Molecular mechanisms of toxicity and cell damage by chemicals in a human pancreatic beta cell line, 1.1B4. Pancreas $2016 ; 45: 1320-1329$.

31. Scharfmann R, Didiesheim M, Richards P, Chandra V, Oshima M, Albagli O. Mass production of functional human pancreatic $\beta$-cells: why and how? Diabetes Obes. Metab. 2016; 18 Suppl 1: 128-136 
32. Peters A. Incretin-based therapies: review of current clinical trial data. Amer. J. Med. 2010; 123: S28-S37.

33. Kayaniyil S, Lozano-Ortega G, Bennett HA, Johnsson K, Shaunik A, Grandy S, Kartman B. A network meta-analysis comparing exenatide once weekly with other GLP-1 receptor agonists for the treatment of Type 2 diabetes mellitus. Diabetes Ther. 2016; 7: 27-43.

34. Srinivasan D, Mechkarska M, Abdel-Wahab YH, Flatt PR, Conlon JM. Caerulein precursor fragment $(\mathrm{CPF})$ peptides from the skin secretions of Xenopus laevis and Silurana epitropicalis are potent insulin-releasing agents. Biochimie 2013; 95: 429-435.

35. Wieprecht T, Dathe M, Krause E, Beyermann M, Maloy WL, MacDonald DL, Bienert M. Modulation of membrane activity of amphipathic, antibacterial peptides by slight modifications of the hydrophobic moment. FEBS Lett. 1997; 417: 135-140.

36. Wieprecht T, Dathe M, Epand RM, Beyermann M, Krause E, Maloy WL, MacDonald DL, Bienert M. Influence of the angle subtended by the positively charged helix face on the membrane activity of amphipathic, antibacterial peptides. Biochemistry 1997; 36: 1286912880.

37. Stark M, Liu LP, Deber CM. Cationic hydrophobic peptides with antimicrobial activity. Antimicrob. Agents Chemother. 2002; 46: 3585-3590.

38. Weiss S, Oz S, Benmocha A, Dascal N. Regulation of cardiac L-type $\mathrm{Ca}^{2+}$ channel CaV1.2 via the $\beta$-adrenergic-cAMP-protein kinase A pathway: old dogmas, advances, and new uncertainties. Circ. Res. 2013; 113: 617-631.

39. Drucker DJ. Glucagon-like peptide-1 and the islet beta-cell: augmentation of cell proliferation and inhibition of apoptosis. Endocrinology 2003; 144: 5145-51488. 
40. Lee YS, Jun HS. Anti-diabetic actions of glucagon-like peptide-1 on pancreatic beta-cells. Metabolism. 2014; 63: 9-19.

41. Shimoda M, Kanda Y, Hamamoto S, Tawaramoto K, Hashiramoto M, Matsuki M, Kaku K. The human glucagon-like peptide-1 analogue liraglutide preserves pancreatic beta cells via regulation of cell kinetics and suppression of oxidative and endoplasmic reticulum stress in a mouse model of diabetes. Diabetologia. 2011; 54: 1098-1108.

42. Tokuda M, Katsuno T, Ochi F, Miyakoshi K, Kusunoki Y, Murai K, Miuchi M, Hamaguchi T Miyagawa J, Namba M. Effects of exenatide on metabolic parameters/ control in obese Japanese patients with type 2 diabetes, Endocr. J. 2014; 61: 365-372.

43. Morris DL. Minireview: emerging concepts in iIslet macrophage biology in Type 2 diabetes. Mol. Endocrinol. 2015; 29: 946-962.

44. Cnop M, Welsh N, Jonas JC, Jörns A, Lenzen S, Eizirik DL.Mechanisms of pancreatic beta-cell death in type 1 and type 2 diabetes: many differences, few similarities. Diabetes 2005; 54 Suppl 2: S97-107.

45. Conlon JM, Power GJ, Abdel-Wahab YH, Flatt PR, Jiansheng H, Coquet L, Leprince J, Jouenne T, Vaudry H. A potent, non-toxic insulin-releasing peptide isolated from an extract of the skin of the Asian frog, Hylarana guentheri (Anura:Ranidae). Regul. Pept. 2008; 151: 153-159.

46. Islam MS, du Loots T. Experimental rodent models of type 2 diabetes: a review. Methods Find. Exp. Clin. Pharmacol. 2009; 31: 249-261.

47. Wang CY, Liao JK. A mouse model of diet-induced obesity and insulin resistance. Methods Mol. Biol. 2012; 821: 421-433. 

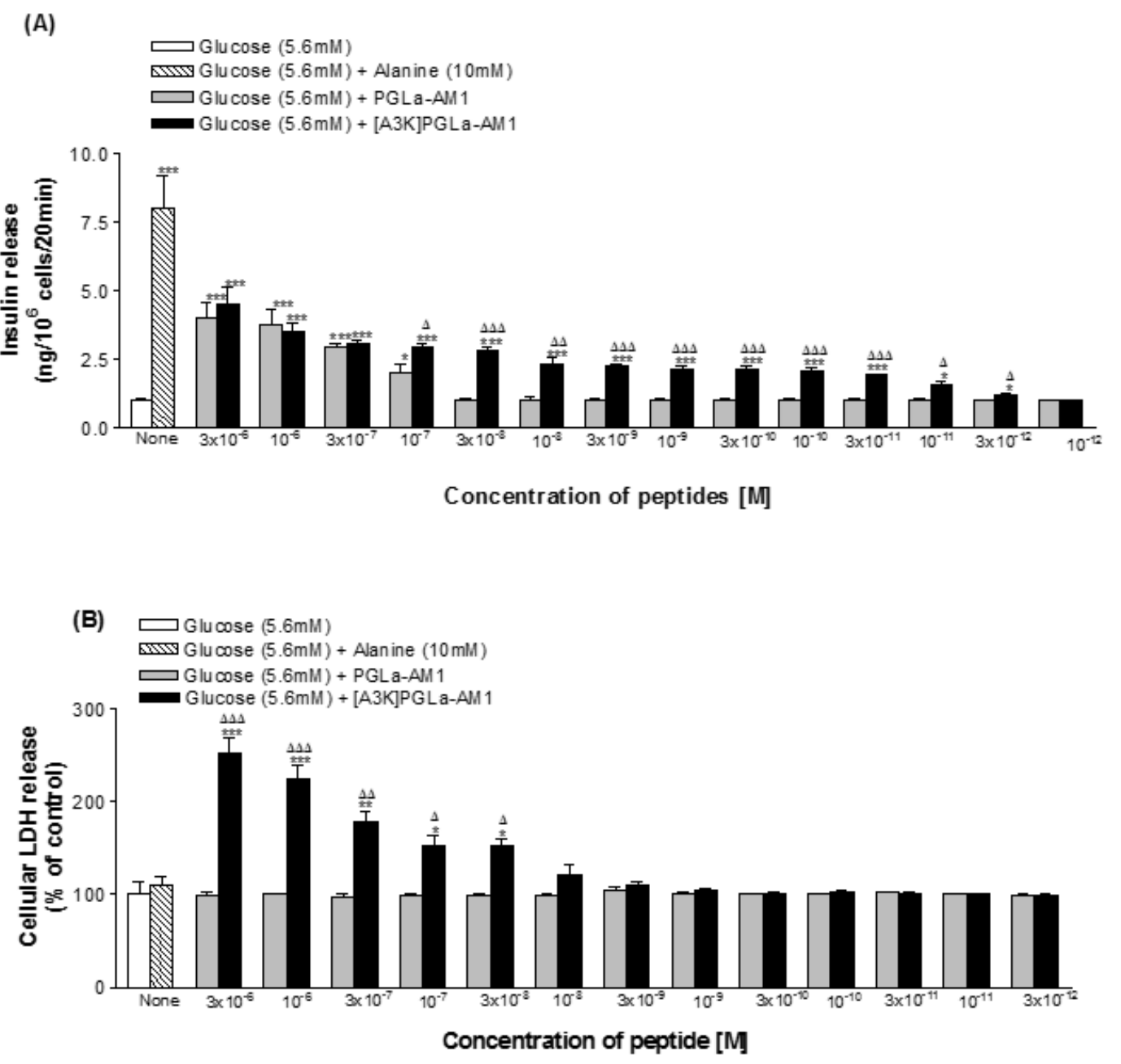

Supplementary Fig. 1. Comparison of the effects of [A3K]PGLa-AM1 with PGLa-AM1 on (A) insulin release and (B) LDH release from BRIN-BD11 cells Values are mean \pm SEM, $\mathrm{n}=8$ for insulin release and $\mathrm{n}=4$ for $\mathrm{LDH}$ release. $* \mathrm{P}<0.05, * * \mathrm{P}<0.01 * * * \mathrm{P}<0.001$ compared to $5.6 \mathrm{mM}$ glucose alone. ${ }^{\Delta} \mathrm{P}<0.05,{ }^{\Delta \Lambda} \mathrm{P}<0.01,{ }^{\Delta \Delta \Lambda} \mathrm{P}<0.001$ compared to PGLaAM1. 

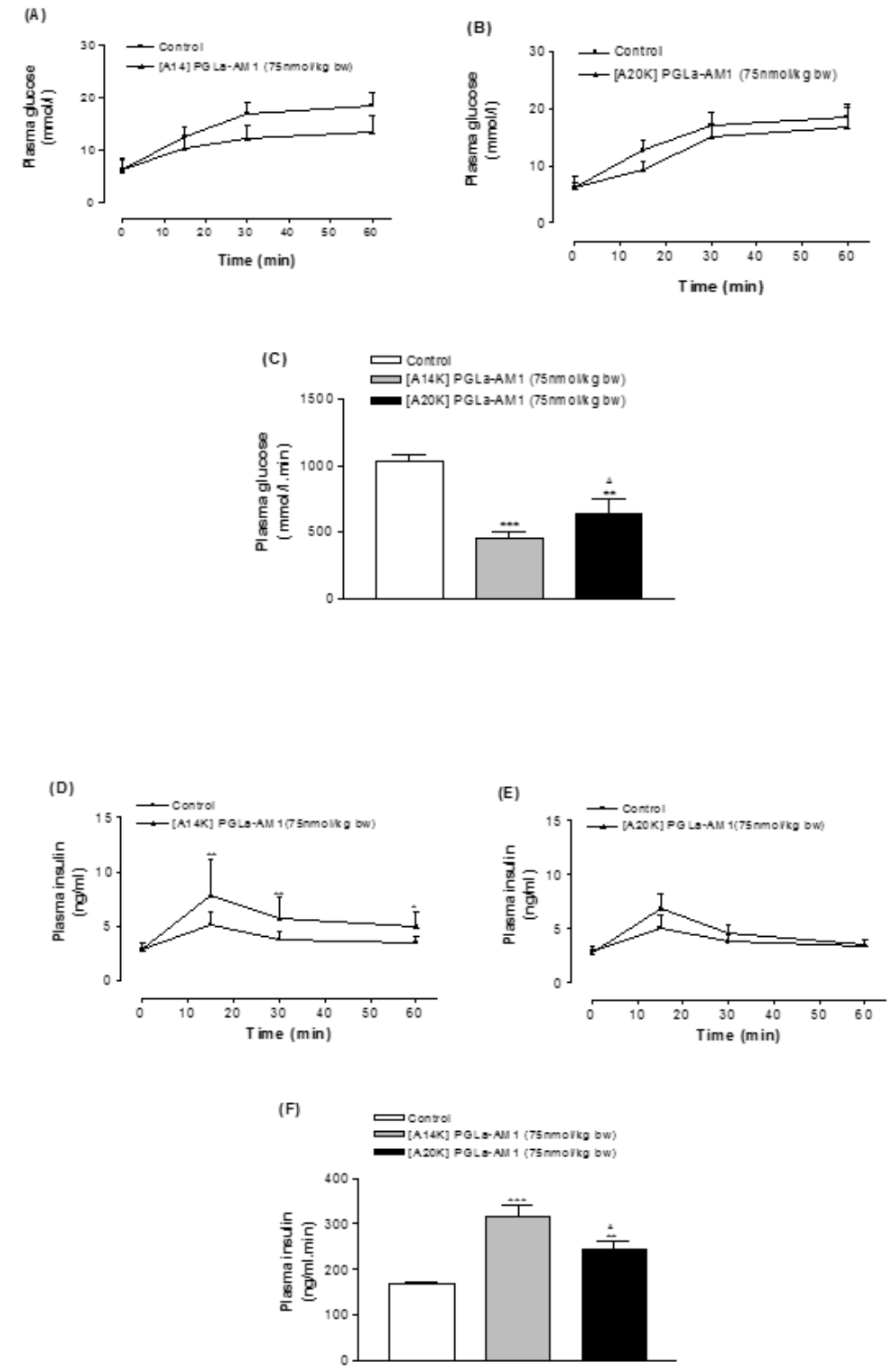

Supplementary Fig. 2. Effects of acute administration of [A14K]PGLa-AM1 (75 nmol/kg body weight) and [A20K]PGLa-AM1 (75 nmol/kg body weight, E-H) on blood glucose (panels A-C) and plasma insulin (panels D-F) concentrations in high fat fed mice after intraperitoneal injection of glucose $\left(18 \mathrm{mmol} / \mathrm{kg}\right.$ body weight). Values are mean $\pm \operatorname{SEM}(\mathrm{n}=8) .{ }^{*} \mathrm{P}<0.05,{ }^{*} \mathrm{P}$ $<0.01 * * * \mathrm{P}<0.001$ compared to glucose alone. 